University of Wollongong

Research Online

Faculty of Business - Papers (Archive)

Faculty of Business and Law

2013

mHealth technologies for chronic diseases and elders: A systematic review

Giovanni Chiarini

Politecnico di Milano

Pradeep Ray

University of New South Wales, p.ray@unsw.edu.au

Shahriar Akter

University of Wollongong, sakter@uow.edu.au

Cristina Masella

Politecnico di Milano

Aura Ganz

University of Massachusetts

Follow this and additional works at: https://ro.uow.edu.au/buspapers

Part of the Business Commons

Research Online is the open access institutional repository for the University of Wollongong. For further information contact the UOW Library: research-pubs@uow.edu.au 


\title{
mHealth technologies for chronic diseases and elders: A systematic review
}

\begin{abstract}
mHealth (healthcare using mobile wireless technologies) has the potential to improve healthcare and the quality of life for elderly and chronic patients. Many studies from all over the world have addressed this issue in view of the aging population in many countries. However, there has been a lack of any consolidated evidence-based study to classify mHealth from the dual perspectives of healthcare and technology. This paper reports the results of an evidence-based study of mHealth solutions for chronic care amongst the elderly population and proposes a taxonomy of a broad range of mHealth solutions from the perspective of technological complexity. A systematic literature review was conducted over 10 online databases and the findings were classified into four categories of predominant mHealth solutions, that is, self-healthcare, assisted healthcare, supervised healthcare and continuous monitoring. The findings of the study have major implications for information management and policy development in the context of the Millennium Development Goals (MDGs) related to healthcare in the world.
\end{abstract}

\section{Keywords}

era2015, chronic, review, diseases, mhealth, elders, technologies, systematic

Disciplines

Business

\section{Publication Details}

Chiarini, G., Ray, P., Akter, S., Masella, C. \& Ganz, A. (2013). mHealth technologies for chronic diseases and elders: A systematic review. IEEE Journal on Selected Areas in Communications, 31 (9), 6-18. 


\title{
mHealth Technologies for Chronic Diseases and Elders: A Systematic Review
}

\author{
Giovanni Chiarini, Pradeep Ray, Senior Member, IEEE, Shahriar Akter, Cristina Masella and \\ Aura Ganz, Fellow, IEEE
}

\begin{abstract}
Health (healthcare using mobile wireless technologies) has the potential to improve healthcare and the quality of life for elderly and chronic patients. Many studies from all over the world have addressed this issue in view of the aging population in many countries. However, there has been a lack of any consolidated evidence-based study to classify mHealth from the dual perspectives of healthcare and technology. This paper reports the results of an evidence-based study of mHealth solutions for chronic care amongst the elderly population and proposes a taxonomy of a broad range of $\mathrm{mHealth}$ solutions from the perspective of technological complexity. A systematic literature review was conducted over 10 online databases and the findings were classified into four categories of predominant mHealth solutions, that is, self-healthcare, assisted healthcare, supervised healthcare and continuous monitoring. The findings of the study have major implications for information management and policy development in the context of the Millennium Development Goals (MDGs) related to healthcare in the world.
\end{abstract}

Index Terms-chronic, elderly, IT artifact, mobile health, taxonomy, technologies, ubiquitous health.

\section{INTRODUCTION}

$\mathrm{M}$ health (healthcare using mobile wireless technologies, also called mobile health technologies) has the potential to transform the healthcare system in aging societies by opening up novel opportunities for global access to health services and medical care for chronic diseases.

Manuscript received April 16, 2012.

Giovanni Chiarini and Cristina Masella are with the Dept. of Management, Economics and Industrial Engineering (DIG), Politecnico di Milano, Italy (e-mail: giovanni.chiarini@mail.polimi.it). Pradeep Ray is with the School of Information Systems, University of New South Wales, NSW 2052, Australia (e-mail: p.ray@unsw.edu.au).

Shahriar Akter is with the School of Management \& Marketing, University of Wollongong, Australia (e-mail: skater@uow.edu.au).

Aura Ganz is with the Electrical \& Computer Engineering Department, University of Massachusetts (e-mail: ganz@ecs.umass.edu).
According to the United Nation's 2009 World Population Ageing report, the number of people aged 60 years or over was 600 million in 2000, a tripling of what it was in 1950, and over the span of the next 40 years, this number is projected to triple once again, taking the count to 2 billion. Furthermore, the average age of people over 60 is increasing: currently, one in every seven people in this age group is 80 years or above and by 2050, one in five will be 80 or over, with nearly fourfifths of them living in less developed regions [1]. Additionally, the total number of persons globally who report a long-standing health problem or disability is 860 million, with NCDs (i.e. non-communicable diseases, such as, cardiovascular diseases and diabetes, cancers and chronic respiratory diseases) still the leading cause of death in the world [2]. In this context, mobile health technologies are playing an instrumental role in serving patients by making healthcare more affordable, accessible and available. The ITU report [3] shows that at the end of 2009, there were approximately 4.6 billion mobile cellular subscriptions, with the average penetration rate, in developed countries, of above $100 \%$. Moreover, the latest generation of smartphones are increasingly viewed as handheld computers rather than as phones, due to their powerful on-board computing capability, capacious memories, large screens and open operating systems that encourage application development [4]. Therefore, it is clear that the potential for mobile technologies to transform healthcare and clinical intervention in the community is tremendous (between $\$ 1.96$ billion and $\$ 5.83$ billion in saved healthcare costs worldwide by 2014 [5]) especially in assisting elders and people with chronic conditions to live independently. In fact, in a recent Price Waterhouse Cooper report, the global mobile health market is expected to reach US $\$ 23$ billion by 2017. Among the various categories, monitoring services will account for the largest share globally (approximately 65\%), and they will be driven primarily by solutions that aid chronic disease management (US $\$ 10.7$ billion) and independent aging (US $\$ 4.3$ billion), with revenues accruing from both developed countries and large developing countries, such as China and India [6]. 
Currently, the key stakeholders-mobile operators, device vendors, healthcare providers, content players, foundations and governments-have already launched several mHealth services and applications worldwide [6] and, at the moment, the GSMA tracker [7] reports more than 300 commercial deployments globally. In particular, developments in new mHealth solutions and technologies specifically for the elderly are steadily proliferating [8-10] and to date, they have targeted a wide range of applications such as: medication adherence, vital signs' monitoring, activity monitoring and alert systems, wellness and rehabilitation, remote consultation, and solutions for caregivers [11]. However, at the moment, the most successful smartphone applications (apps) are generally targeted only to younger and healthier populations [4], while the solutions for seniors face resistance due usually to preconceptions about cost, lack of awareness about what is available, and caution about sharing personal health information [11]. In fact, the higher adoption rate of smartphones by older people and people with chronic disease will depend on cost, easy to use apps, awareness and the type of technology [4]. It is noteworthy that technologies differ on a broad scope and scale, ranging from simple "stand-alone" direct-to-individual smartphone applications to a more complex mobilebased system, enabling continuous interactions amongst patients, caregivers and clinicians anytime and anywhere. As a result, the increasing number of applications, the variety of technologies, and newly introduced terminology (e.g. mHealth; u-health; wireless health [12]; m-IoT [13] etc.) make it difficult to understand these solutions under an hierarchy of IT artifacts [14].

The aim of this paper is primarily to propose a taxonomy of different categories of mobile platforms currently implemented in this area through a systematic review of experiences reported in the literature in the last five years. We believe that the taxonomy can represent an information management strategy to improve knowledge sharing, facilitate policy initiatives, and provide some guidance for the orderly development of new mobile health solutions for the elderly [15]. Furthermore, for practitioners and managers, the systematic review helps in developing a reliable evidence base by providing collective insights through theoretical synthesis [16].

\section{RESEARCH METHOD}

A systematic literature review is a means of identifying, evaluating and interpreting all available research relevant to a particular research question, or topic area, or phenomenon of interest [17]. Although this rigorous evidence-based approach has been used especially in medical science research, the movement to base practice on the best available evidence has migrated from medicine to other disciplines [16]. In this study, the steps used to perform the systematic review are based on the original guidelines proposed by Kitchenham [17], [18], for software engineering research combined with the systematic review process applied in the management field [16]. In particular, the phases undertaken are as follows:

- $\quad$ Planning the review (Section III)

- $\quad$ Conducting the review (Section IV)

- $\quad$ Reporting the review (Section V).

\section{PLANNING THE REVIEW}

In order to determine the most appropriate search strategy, an initial scoping study was conducted, and the outcomes of this process were discussed with other researchers and captured in a review protocol with explicit descriptions of the methods used and the steps to be taken. A pre-defined protocol is often necessary to reduce the possibility of researcher bias [18]. The main information about the search strategy contained in the protocol were: (1) the most appropriate search terms identified, (2) the resources to be searched (including databases, specific journals, and conference proceedings), and (3) the criteria for inclusion/exclusion of studies in the review.

\section{A. Searched terms}

In order to identify the most appropriate search terms, we adapted the experimental findings proposed by Dieste et al. [19] concerning the development of an optimum search strategy. Taking the objective of this review to survey the largest possible number of empirical mHealth solutions, the term "mobile health" was searched $^{1}$, and in each of the first 100 results, all the terms related to "mobile health" were identified. Based on the most recurring terms retrieved, "application”, “system”, “device” and “sensor” were finally considered. Intentionally, due to our objective to review every possible type of mobile-based platform, we did not use terms referring only to a specific category of mobile technologies (e.g. PDAs, tablets, cell phones, smartphones, etc.). Similarly, in the effort to be comprehensive, we also considered all the possible

\footnotetext{
${ }^{1}$ The database used for all the trial pilot searches was Google Scholar, considering publications in which the keyword occurs "anywhere in the article", written in English, between 2008 and 2012 and in the field of "Engineering, Computer Science, and Mathematics."
} 
TABLE 2 - KEYWORDS SELECTION STUDY.

\begin{tabular}{lccc}
\hline \multicolumn{1}{c}{ Keywords } & $\begin{array}{c}\text { Articles } \\
\text { retrieved: }\end{array}$ & $\begin{array}{c}\text { Total } \\
\text { citations: }\end{array}$ & $\begin{array}{c}\text { Years } \\
\text { range }\end{array}$ \\
\hline pervasive healthcare & 1040 & 3718 & 5 \\
mobile health & 908 & 2090 & 5 \\
m-health & 718 & 2044 & 5 \\
wireless health & 683 & 1537 & 5 \\
pervasive health & 679 & 2818 & 5 \\
mobile healthcare & 667 & 1668 & 5 \\
ubiquitous healthcare & 591 & 1410 & 5 \\
ubiquitous health & 507 & 1358 & 5 \\
wearable health & 418 & 1364 & 5 \\
mobile telemedicine & 311 & 894 & 5 \\
u-healthcare & 298 & 506 & 5 \\
wireless healthcare & 249 & 596 & 5 \\
wireless telemedicine & 245 & 856 & 5 \\
u-health & 237 & 270 & 5 \\
mhealth & 175 & 495 & 5 \\
wearable healthcare & 174 & 818 & 5 \\
uhealthcare & 12 & 16 & 5 \\
mhealthcare & 8 & 23 & 3 \\
uhealth & 6 & 11 & 5 \\
\hline
\end{tabular}

abbreviations, alternative spellings, and combinations of terms usually related to the meaning of "mobile health" and extracted from the scoping study, the literature and discussions with other researchers. Afterwards, we ranked this list of terms, selecting those words that maximized the sensitivity rate (estimated by the total number of articles retrieved ${ }^{1}$ with such keywords, see
Table 2). Finally the terms "chronic” and "elderly” were added with the expectation that publications relating to these categories of patients would contain these terms at least once in the full text. To summarize, depending on the search services offered by each selected search engine, the full text of the journal articles and conference proceedings were searched using the following search strings:

- chronic AND (application OR system OR device OR sensor) AND ("pervasive healthcare" OR "mobile health" OR "mhealth" OR "wireless health" OR "pervasive health" OR "mobile healthcare" OR "ubiquitous healthcare" OR "wearable health")

- elderly AND (application OR system OR device OR sensor) AND ("pervasive healthcare" OR "mobile health" OR “mhealth" OR "wireless health" OR "pervasive health" OR "mobile healthcare" OR "ubiquitous healthcare" OR "wearable health")

\section{B. Resources searched}

The journals and conference proceedings published in English between 2008 and 2012 were searched with the keywords noted in the previous section using 10 online databases: SpringerLink; ScienceDirect; Wiley InterScience; Liebert Online; Journal of Telemedicine and Telecare; Scirus; IEEE Xplore; ACM Digital

TABLE 1 - SetTINGS USED FOR SEARCHES ON ONLINE DATABASES AND THE ARTICLES FOUND.

\begin{tabular}{|c|c|c|c|c|c|}
\hline Database & Subjects & Field & Document Type & $\begin{array}{c}\text { Numbers of } \\
\text { non- repeated } \\
\text { articles }\end{array}$ & $\begin{array}{c}\text { Number of } \\
\text { repeated articles }\end{array}$ \\
\hline SpringerLink & Engineering, Computer Science & Full Text & Journal Articles & 34 & - \\
\hline ScienceDirect & Computer Science, Decision Science, Eng. & Full Text & Journals & 61 & - \\
\hline Wiley InterScience & ALL & Full Text & Journals & 205 & - \\
\hline Liebert Online & Engineering/Informatics & ALL Fields & Journals & 44 & - \\
\hline J. of Telemedicine & ALL & Full Text & Articles & 8 & - \\
\hline Scirus & ALL & $\begin{array}{l}\text { Title, } \\
\text { Keywords }\end{array}$ & $\begin{array}{l}\text { Articles, } \\
\text { Conferences }\end{array}$ & 34 & $\begin{array}{l}15 \text { from the above } \\
\text { databases }\end{array}$ \\
\hline IEEE Xplore & $\begin{array}{l}\text { Computing \& Processing - Components, } \\
\text { Circuits, Devices \& Systems - Communication, } \\
\text { Networking \& Broadcasting - Bioengineering }\end{array}$ & $\begin{array}{l}\text { Title, } \\
\text { Keywords, } \\
\text { Abstract }\end{array}$ & $\begin{array}{l}\text { Journals, } \\
\text { Conferences }\end{array}$ & 487 & $\begin{array}{l}8 \text { from the above } \\
\text { databases }\end{array}$ \\
\hline $\begin{array}{l}\text { ACM Digital } \\
\text { Library }\end{array}$ & ALL & ALL Fields & $\begin{array}{l}\text { Journals, } \\
\text { Proceedings }\end{array}$ & 140 & $\begin{array}{l}8 \text { from the above } \\
\text { databases }\end{array}$ \\
\hline CiteSeer & ALL & Full Text & ALL & 13 & $\begin{array}{l}4 \text { from the above } \\
\text { databases }\end{array}$ \\
\hline Google Scholar & $\begin{array}{l}\text { Engineering, Computer Science, and } \\
\text { Mathematics }\end{array}$ & Full Text & ALL & 1395 & $\begin{array}{l}331 \text { from the } \\
\text { above databases }\end{array}$ \\
\hline & & & Total & 2421 & 366 \\
\hline \multicolumn{4}{|c|}{ Number of non-repeated papers found } & 2055 & \\
\hline
\end{tabular}


Library; CiteSeer; and Google Scholar. Due to the multidisciplinary nature of the field investigated (mobile health), the articles were searched through a comprehensive list of subjects, but the main focus remained on a technological perspective, in accordance with the review question. The names of databases, the subjects, the document types, and the data ranges used are listed in Table 1.

\section{Inclusion/exclusion criteria}

Even though, for the purpose of comprehensiveness, each term (often used interchangeably) relating to "mobile health" was considered (Table 2), the research question focused on investigating only those solutions reported in the literature that were truly mobile. Adopting the definition given by Akter and Ray [20], we considered these solutions "as a personalized and interactive service whose main goal is to provide ubiquitous and universal access to medical advice and information to any users at any time over a mobile platform". Derived from this definition, we incorporated into the review only those studies that meet all the inclusion criteria and which manifest none of the exclusion criteria listed below.

We included the solutions:

1) that reflect only the current situation: published between 2008 and January 2012 and have already been developed and implemented.

2) whose patient-centric architecture was designed to work in full mobility: composed of mobile/wearable devices which allow the patient to move not only in the proximity of a fixed-base station or within a limited sensor-equipped environment (i.e. ambient intelligence, such as smart-homes or hospitals). At the same time, clinicians and caregivers could use or not use other mobile-based devices to monitor the patient.

3) that were specifically targeted to satisfy a need of a chronic/elderly patient or their caregivers. According to [9], these key needs usually refer to: health monitoring needs, personal information needs, social needs, leisure and sales needs, and safety and privacy needs. We did not include generic applications for wellness or healthcare purposes, such as, emergency medical service (EMS) or electronic health record (EHR) for generic patients.

We excluded the solutions which were:

1) not in English or for which the full text was not available online.

2) focused only on:

a. design methodologies, conceptual frameworks and models; b. data management: quality, security, privacy, and legal and regulatory issues;

c. mobile communication technologies, protocols and standards;

d. technological innovations of single components (e.g. power consumption, miniaturization, computational capabilities..)

3) not based on an empirical application (i.e. opinions, viewpoints, future trends, etc.).

4 in the form of book chapters, guest editorials, tutorials, correspondence, poster sessions, roundtable discussions, comments, prefaces, article summaries, interviews and correspondence.

Rather than formally applying any quality assessment criteria to the articles to be included in our review, we preferred to rely on the implicit quality rating of the extracted journals.

\section{CONDUCTING THE REVIEW}

The main stages followed in the review process are described below. In order to reach the outcomes, presented in section V.A, some popular software applications were used for the bibliography retrieval (Zotero), document management (Mendeley), and data extraction and analysis (Excel).

\section{A. Identification of resources}

The two strings of keywords (Section III.A) were searched in each of 10 scientific databases (Section III.B). For each database, the results in common between the two strings were excluded, and the number of remaining articles was noted (Table 1). Similarly, these articles were compared with the results from all the other databases and 366 repeated publications were excluded. Finally, a list of 2055 primary studies was identified.

\section{B. Selection}

Figure 1 shows the steps involved in the study selection which follows the multistage process suggested by Kitchenham's guidelines [17]. Initially, we started with the 2055 non-repeated papers identified in the previous section (Stage 1). In stage 2, we excluded 837 studies based on their titles $(n=1219)$. In most cases, to be able to clearly assess whether each inclusion/exclusion criterion (section III.C) was met or not, we had to read the abstracts (Stage 3) or the full text (Stage 4). Thus, we excluded 945 publications $(n=274)$ on the basis of their abstracts and 232 by reading the full texts. When several publications were derived from the same mHealth platform, only the publication most recent or most aligned to the defined criteria was included. Finally, after these exclusions (Stages 2-4), the systematic review resulted in 42 unique relevant solutions. 
FIGURE 1 - SELECTION PROCESS.

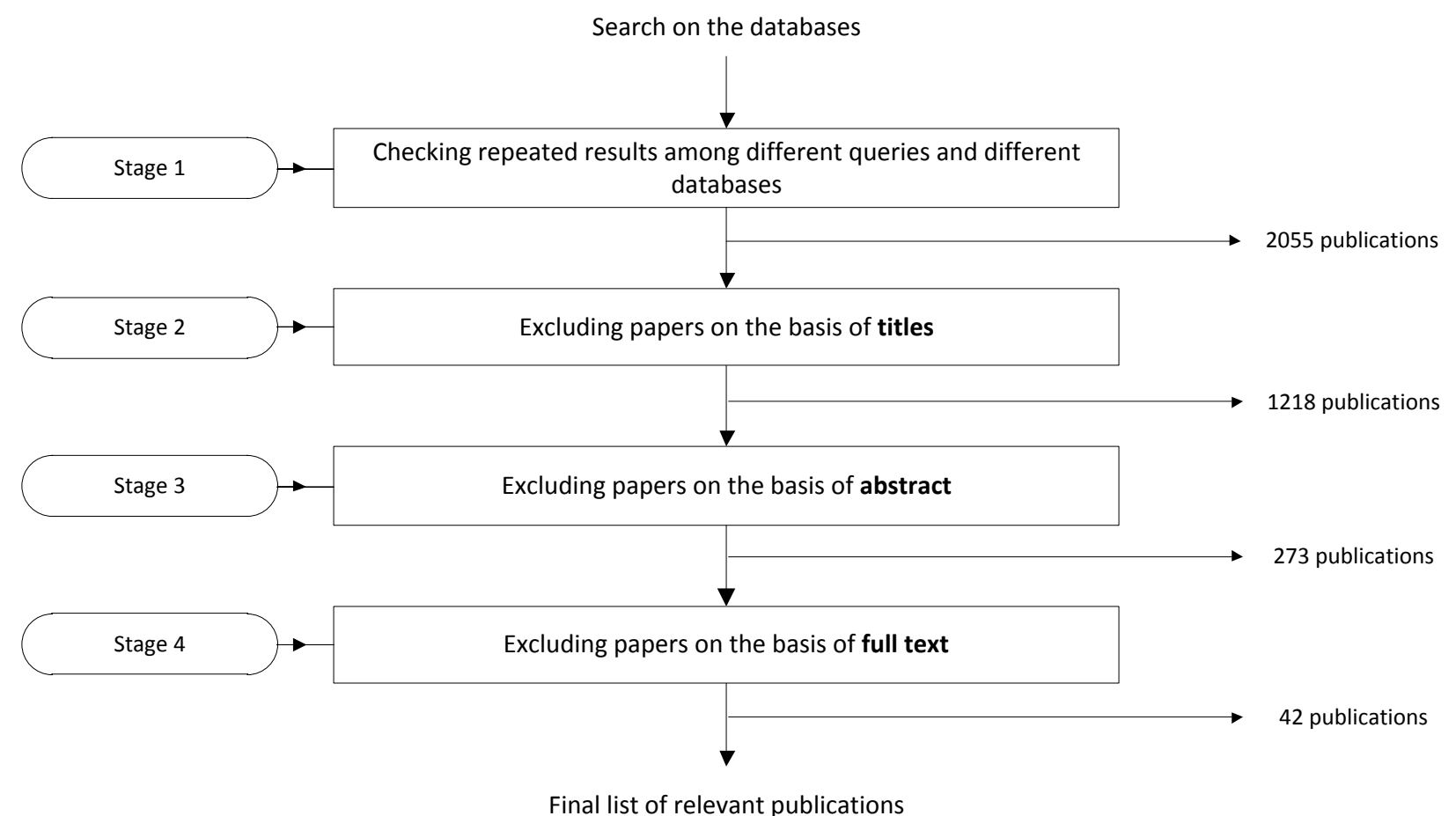

\section{Data extraction and synthesis}

The objective of this stage was to extract and synthesize key details from the final 42 papers. For this purpose, an electronic form was employed, to reduce human error and bias [16], [17], and facilitate subsequent analysis. The types of data extracted from the studies were as follows: (1) demographics, to record the year of publication, country, source name and type (journal/conference proceedings) and key characteristics of the solutions analyzed. According to the threedimensional model provided by Bashshur et al. [15], we grouped these characteristics into: (2) the functions that are performed, (3) the specific applications, and (4) the technological components. Afterwards, based on the review objective, data were synthesized solely by recognizing the different technological configurations reported in the publications.

\section{Data analysis}

The whole analysis process undertaken for the final list of publications is shown in Figure 2. Firstly, the high-level technological infrastructure of each mHealth solution retrieved was analyzed and broken down into the key elements (Stages 1-2). In order to make more sense of the extracted technological components, we sought to categorize them, based on the usual three-tier architectural model for a personal health system (PHS) presented by Shopov et al. In brief, even though there is no standard definition of the structure of PHSs, most of the implementations integrated the following major blocks into their design: I) a network of biosensors (BSN); II) a personal mobile gateway, and III) different remote medical servers [21]. Secondly, the identified system structures were compared, and similar ones were grouped into four meaningful clusters on the basis of attributes (frequency, direction, extent) of the information flow exchanged between the patient and the caregiver $^{2}$ (Stages 3-4). As suggested by Ludwig et al. [22], we used the information flow exchanged between the users, services, and components of the system, as an indicator for the complexity of the sensor-enhanced trans-institutional information system architectures.

Finally, in stage 5, taking into consideration the above points, we assigned a specific label and definition to each category and, through the combination of these four different types of interactions supported by specific technological configurations, a taxonomy of the existing mhealth platform was derived.

\footnotetext{
${ }^{2}$ We considered and we will use through the next sections the general word "caregiver" to refer to both a health-related worker (physician, nurse, care-center staff member) or an informal caregiver (person of trust for the patient).
} 


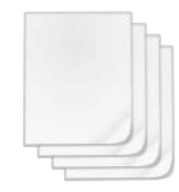

Final list of papers

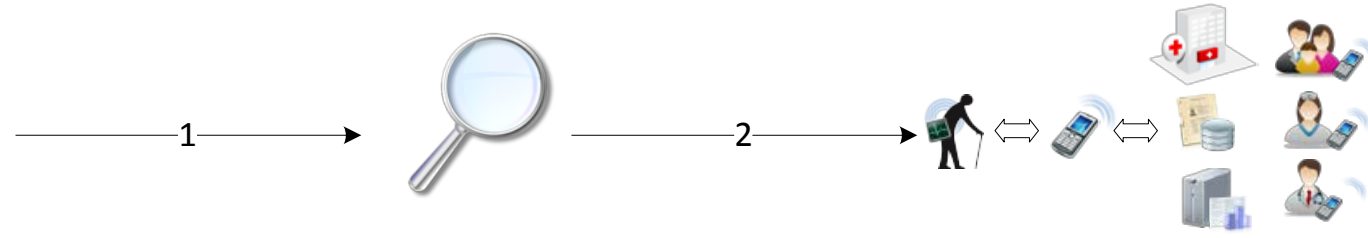

Studying the high level infrastructure of each $\mathrm{m}$-health solution

Extracted key components
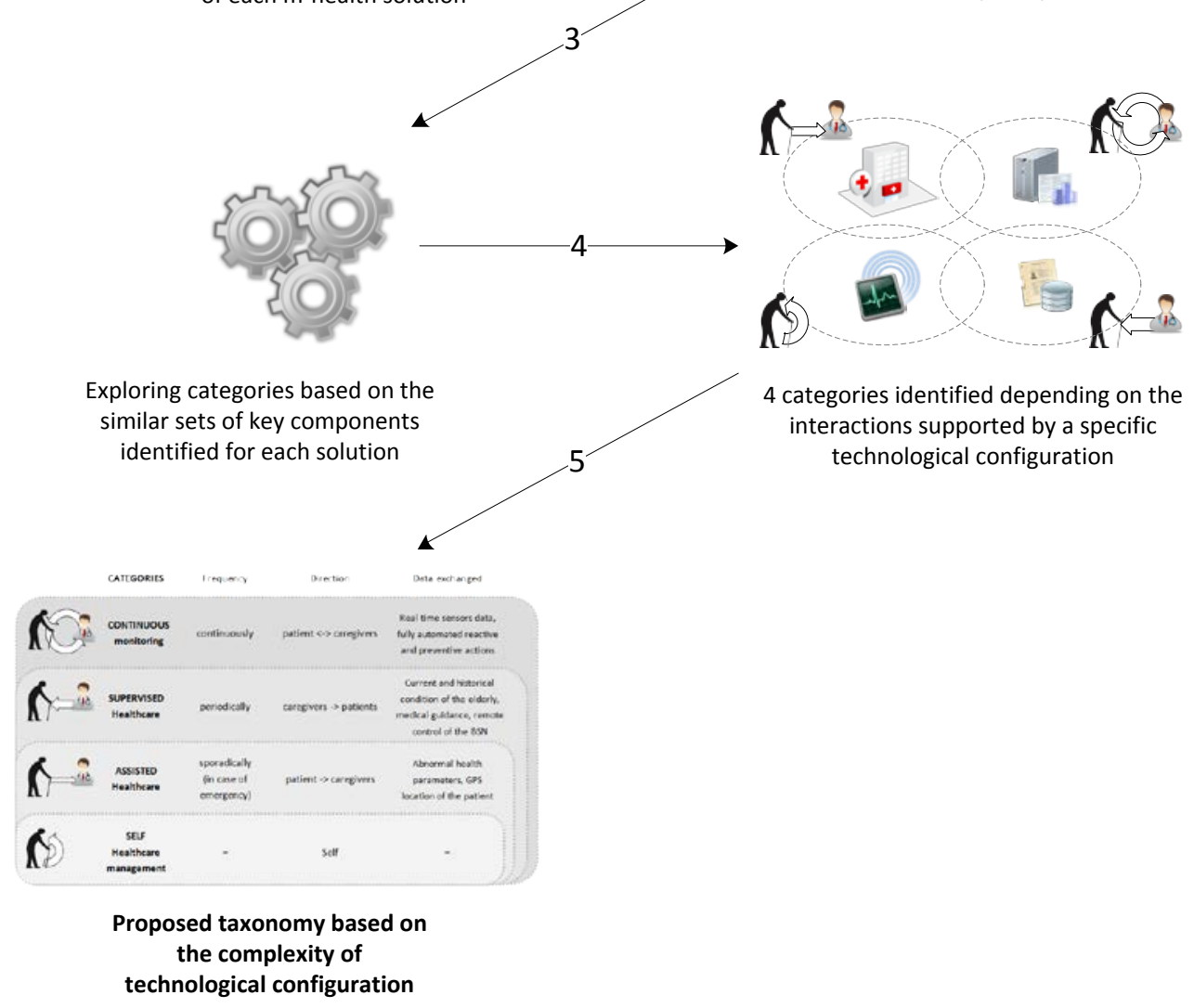

FIGURE 2 - DATA ANALYSIS PROCESS.

\section{REPORTING THE REVIEW}

In our review, we investigated the current status of existing mobile health technologies and solutions that have been implemented for the elderly and patients with chronic conditions and have been reported in the literature. After analysis of the selected publications, we identified four main categories for these solutions. The following sections present (1) the results of this study through the proposed taxonomy of existing solutions and some aggregate (2) demographic data extracted from the final list of papers.

\section{A. Results}

Figure 3 depicts the taxonomy of the four types of solutions, identified on the basis of 42 existing mobile health systems extracted from the literature. The following sections provide detailed explanations and examples for each category, namely: self-healthcare management, assisted healthcare, supervised healthcare and continuous monitoring. 


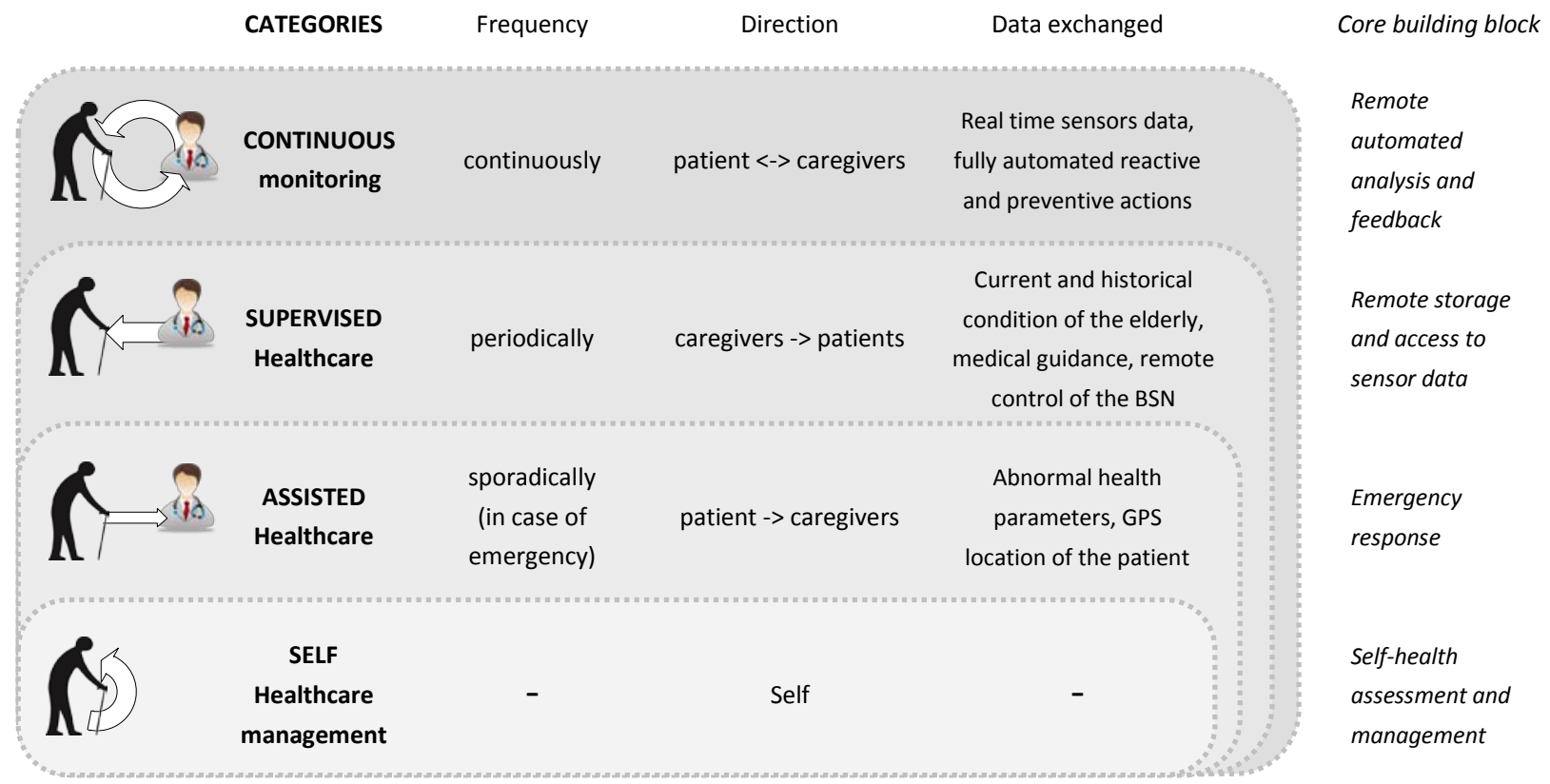

FIGURE 3 - OUR TAXONOMY OF THE MHEALTH SOLUTIONS.

\section{1) Self-healthcare management}

Self-healthcare management is focused on the autonomy, engagement and self-confidence of aging people, without the need for involvement of an external caregiver in the delivery of the mHealth service (Table 3). These solutions usually consist of a body sensor network (BSN) and a mobile-based unit (MBU). The BSN is a network of miniaturized, low cost, and wireless wearable or implantable biosensors and actuators that are interconnected to collect the patient's physiological and contextual parameters [21], for example ECG, EEG, $\mathrm{SpO}_{2}$, heart and respiration rates, blood pressure, body temperature, glucose level, spatial location, etc. Even if these sensors are not wearable (i.e. embedded in a smart garment, ring, wristband, etc., the mobility of the platform (from the patient's perspective) is still preserved, when it involves other portable external measurement devices or when it simply exploits the built-in smartphone sensors (typically the camera, GPS, accelerometers).

Afterwards, these sensors' data are wirelessly transmitted to the MBU which is responsible for local storage, processing and analysis, in order to provide feedback to the patient, through a user-friendly and interactive graphical or audio interface. In the applications reviewed $(n=42)$, the MBU was, in most cases, a commercial smartphone (34) rather than a PDA (4) or a custom specially-designed mobile processing unit (4).

A representative example of this category is an application proposed by Au et al. [12]: a system which uses on-body acceleration sensors and an ultra-portable PC to automatically detect the occurrence of the freezing of gait (FOG) symptom which occurs in Parkinson's Disease patients and to provide a rhythmic auditory signal that stimulates them to resume walking. Similarly, MoviPill [23] is a smartphone social game that leverages only on the patient engagement in shifting his/her behavior towards better medication compliance. Additionally, De Jager et al. [24] and Hervás et al. [25] show two other proposals for helping elderly people to maintain their autonomy in daily activities, exploring the potential of an augmented-reality iPhone app.

Although some of these solutions require the storing/ processing capabilities of a remote server to provide the feedback to the patient, they do not involve the interactions of any other user. Therefore, all the tasks are performed actively and independently by the elder exchanging information with automated applications.

\section{2) Assisted healthcare}

This category includes solutions which involve not only the self-component ${ }^{3}$ to acquire the measurements of health parameters (see section above), but also engages at least one other user in the process of sharing these data. This only occurs when the patient manually (through an SOS button) or automatically (if the detected health parameters exceed a preset threshold) requests the assistance of an external caregiver, in case of emergency (Table 4). These types of solutions usually add to the basic mobile architecture for selfmeasurements, a care center [28] or at least, other fixed 
TABLE 3 - SELF -HEALthCARE MANAGEMENT SOLUTIONS.

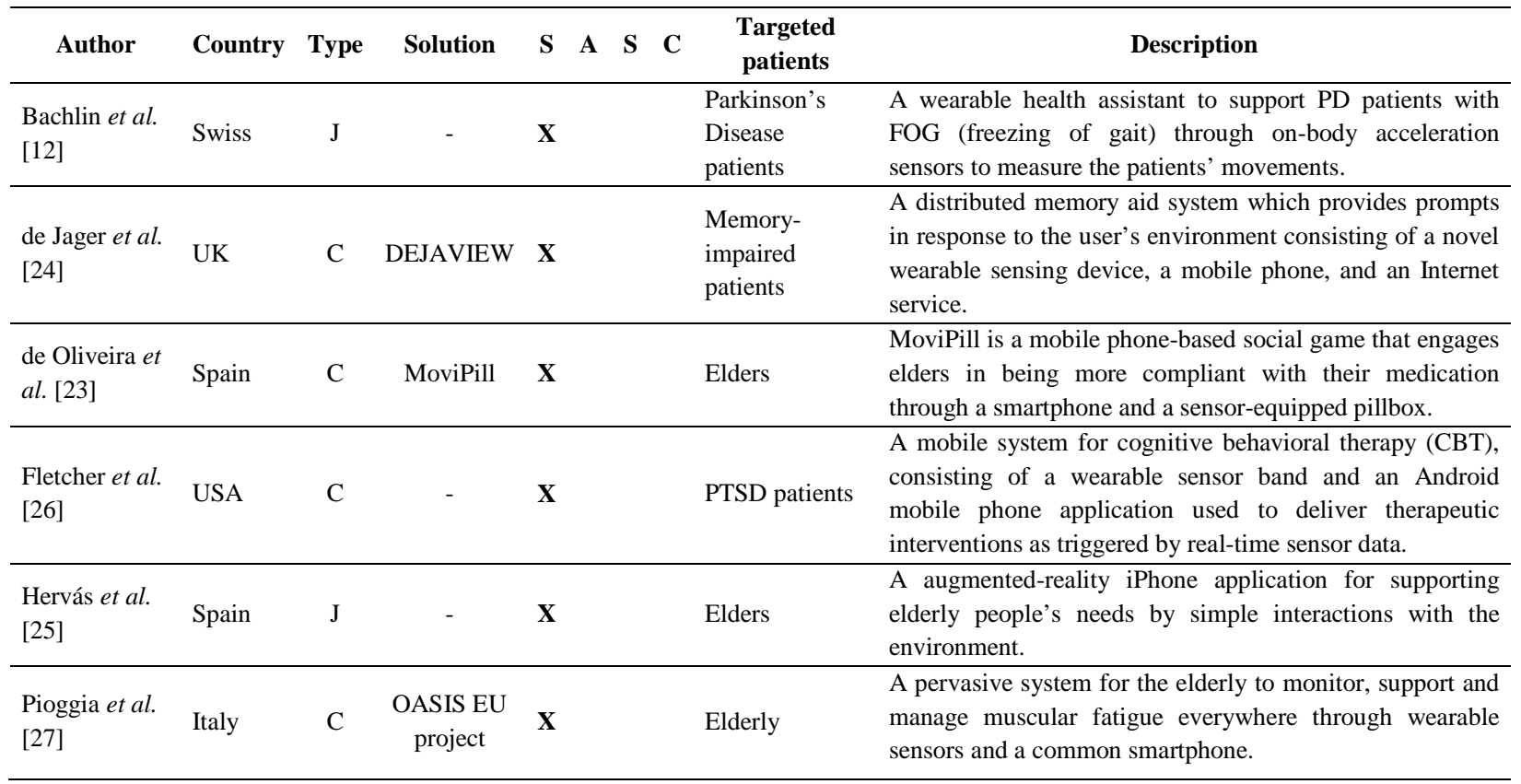

TABLE 4 - AsSISTED HEALTHCARE SOLUTIONS.

\begin{tabular}{|c|c|c|c|c|c|c|c|}
\hline Author & Country & Type & Solution & $\mathbf{S}$ & A $\mathrm{S}$ & $\begin{array}{l}\text { Targeted } \\
\text { patients }\end{array}$ & Description \\
\hline $\begin{array}{l}\text { Bourke et al. } \\
\text { [28] }\end{array}$ & Ireland & $\mathrm{C}$ & - & & $\mathbf{X}$ & Elders & $\begin{array}{l}\text { A fall detection system (sensor device and mobile phone) } \\
\text { incorporated into a custom-designed vest which } \\
\text { automatically detects falls and sends a message to the care } \\
\text { center. }\end{array}$ \\
\hline $\begin{array}{l}\text { Chang et al. } \\
\text { [29] }\end{array}$ & Taiwan & $\mathrm{J}$ & - & & $\mathbf{X}$ & Elders & $\begin{array}{l}\text { A portable fall detection system which places } \\
\text { accelerometers and gyroscopes on parts of the body and } \\
\text { transmits data to a mobile device. }\end{array}$ \\
\hline Dai et al. [30] & China & C & PerFalID & & $\mathbf{X}$ & Elders & $\begin{array}{l}\text { PerFallD utilizes the self-contained communication and } \\
\text { detection (accelerometers) components of a single Android } \\
\text { mobile phone as a platform for a pervasive fall detection } \\
\text { system. }\end{array}$ \\
\hline $\begin{array}{l}\text { Hong et al. } \\
\text { [31] }\end{array}$ & Korea & $\mathrm{J}$ & - & & $\mathbf{X}$ & $\begin{array}{l}\text { Chronic/Elderly } \\
\text { patients }\end{array}$ & $\begin{array}{l}\text { A wearable device that can continuously measure ECG and } \\
\text { motion signals and, on the occurrence of an emergency } \\
\text { situation, transmits (manually or automatically) emergency } \\
\text { situation data to a remote server, where the medical staff } \\
\text { can provide prompt rescue by sending an emergency } \\
\text { message (SMS) to the patient. }\end{array}$ \\
\hline $\begin{array}{l}\text { Hernandez } \\
\text { Munoz et al. } \\
\text { [32] }\end{array}$ & UK & C & Pervalaxis & & $\mathbf{X}$ & $\begin{array}{l}\text { Chronic } \\
\text { Allergic } \\
\text { Patients }\end{array}$ & $\begin{array}{l}\text { A personal health device to help allergic people both in an } \\
\text { emergency scenario (if an anaphylactic reaction occurs) } \\
\text { and during normal life (encouraging them to know, learn, } \\
\text { manage and improve their own health) using a smartphone, } \\
\text { a sensing device and a web-based interface. }\end{array}$ \\
\hline $\begin{array}{l}\text { Kailanto et al. } \\
\text { [33] }\end{array}$ & Finland & $\mathrm{C}$ & $\begin{array}{l}\text { part of } \\
\text { UUTE } \\
\text { project }\end{array}$ & & $\mathbf{X}$ & $\begin{array}{l}\text { Chronic/Elderly } \\
\text { patients }\end{array}$ & $\begin{array}{l}\text { A mobile system using a mobile phone as a base station to } \\
\text { process and analyze signals from an ECG sensor. When } \\
\text { abnormalities are found, part of the signal is sent to a } \\
\text { server for further analysis by medical personnel. }\end{array}$ \\
\hline $\begin{array}{l}\text { Lopes et al. } \\
\text { [34]. }\end{array}$ & Portugal & $\mathrm{J}$ & SensorFall & & $\mathbf{X}$ & Elders & $\begin{array}{l}\text { SensorFall is a PDA or mobile phone application based on } \\
\text { an accelerometer, which allows notification and monitoring } \\
\text { of falls and sends the alarm to the contacts and medical } \\
\text { help, by SMS, phone calls, GPS position, and an audio } \\
\text { alarm. }\end{array}$ \\
\hline
\end{tabular}




\begin{tabular}{|c|c|c|c|c|c|c|}
\hline $\begin{array}{l}\text { Sing-Hui Toh } \\
\text { et al. [35] }\end{array}$ & Korea & C & - & $\mathbf{X}$ & $\begin{array}{l}\text { Chronic } \\
\text { patients }\end{array}$ & $\begin{array}{l}\text { A mobile monitoring system where vital signs are } \\
\text { measured with wearable sensors, analyzed locally on a cell } \\
\text { phone and, in case of abnormal data, forwarded to the } \\
\text { hospital server for doctors' evaluation. }\end{array}$ \\
\hline Wagner [36] & Denmark & C & $\begin{array}{l}\text { part of } \\
\text { OpenCare } \\
\text { project }\end{array}$ & $\mathbf{X}$ & Elders & $\begin{array}{l}\text { This personal communication device (PCD) is a Windows- } \\
\text { based mobile solution which allows the elder to leave } \\
\text { his/her home while continuing the surveillance of his/her } \\
\text { vital signs through sensors, providing access to medication } \\
\text { reminders and allowing easy communication and } \\
\text { emergency location services. }\end{array}$ \\
\hline $\begin{array}{l}\text { Yavuz et al. } \\
\text { [37] }\end{array}$ & Turkey & C & - & X & Elders & $\begin{array}{l}\text { An Android application which, using the built-in } \\
\text { smartphone sensors, can detect the unexpected fall } \\
\text { situation and send the alert (with the location information) } \\
\text { to caregivers via SMS, email or by updating status on a } \\
\text { social network. }\end{array}$ \\
\hline
\end{tabular}

or mobile devices (such as mobile phones or a fixed terminal) where caregivers are warned about abnormal situations, through SMS, phone calls, e-mails, and an audio alarm.

Although some applications generally monitor the values of the vital signs measured [33], [35], [36], most of the solutions of this category found in the literature, are focused specifically on the considerable risks of falls in the elderly population. In particular, they employ wearable sensors placed on an elder's body [28], [29], or utilize built-in smartphone accelerometers and gyroscopes [30], [34], to obtain a ubiquitous fall detection system that can send alarms to contacts and medical help. In the solution presented by Yavuz et al. [37], these alerts can also be sent by updating the status of the elder on his/her social network account.

In brief, these solutions allow the patient, in case of emergency, to rely on the assistance of another user, to whom only the data from a certain range are forwarded (typically with the GPS position of the subject).

TABLE 5 - SUPERVISED HEALTHCARE SOLUTIONS.

\begin{tabular}{|c|c|c|c|c|c|c|c|c|}
\hline Author & Country & Type & Solution & S & A & $\mathrm{S}$ & $\begin{array}{l}\text { Targeted } \\
\text { patients }\end{array}$ & Description \\
\hline Au et al. [12] & USA & $\mathrm{C}$ & WHI-FIT & & & $\mathbf{X}$ & Stroke patients & $\begin{array}{l}\text { A sensor-equipped portable cycle restorator that } \\
\text { continuously measures arm and leg cycling activities } \\
\text { through an Android-based device in real time. }\end{array}$ \\
\hline $\begin{array}{l}\text { Galetic et al. } \\
\text { [38] }\end{array}$ & Croatia & $\mathrm{C}$ & EMH & & $\mathbf{X}$ & $\mathbf{X}$ & $\begin{array}{l}\text { Chronic/Elderly } \\
\text { patients }\end{array}$ & $\begin{array}{l}\text { The EMH solution measures patient's vital signs and } \\
\text { forwards them to medical experts through a set of wearable } \\
\text { sensors worn by patients, a mobile communication device } \\
\text { and a web application used by medical personnel to view } \\
\text { the measurements. }\end{array}$ \\
\hline $\begin{array}{l}\text { Hsiao et al. } \\
\text { [39] }\end{array}$ & Taiwan & $\mathrm{C}$ & - & & $\mathbf{X}$ & $\mathbf{X}$ & Elders & $\begin{array}{l}\text { An outdoor monitoring system composed of a "healthcare } \\
\text { box" that detects whether the patient falls by analyzing } \\
\text { collected information through GPS and an EEG sensor. } \\
\text { The patient's physiological signals are stored and } \\
\text { accessible at the healthcare center by doctors and families. }\end{array}$ \\
\hline Lee et al. [40] & Korea & $\mathrm{J}$ & - & & & $\mathbf{X}$ & Elders & $\begin{array}{l}\text { A u-healthcare platform for monitoring the elderly with } \\
\text { diabetes mellitus or heart disease through an ECG sensor, } \\
\text { glucometer, mobile phones and a web server, where the } \\
\text { measured data is transmitted to and accessed by clinicians. }\end{array}$ \\
\hline $\begin{array}{l}\text { López et al. } \\
\text { [41] }\end{array}$ & Spain & $\mathrm{J}$ & CareTwitter & & & $\mathbf{X}$ & Elders & $\begin{array}{l}\text { A platform which records caring logs in situ through an } \\
\text { RFID wristband and NFC mobile phone in order to } \\
\text { improve data management in a care center keeping } \\
\text { relatives up-to-date with elderly people's evaluation, } \\
\text { through a Web } 2.0 \text { social service. }\end{array}$ \\
\hline Lv et al. [47] & China & C & iCare & & $\mathbf{X}$ & $\mathbf{X}$ & Elders & $\begin{array}{l}\text { iCare is a mobile health monitoring system which, } \\
\text { combining a smartphone, body sensors and web } \\
\text { technology, can monitor the elderly anytime anywhere and } \\
\text { alert pre-assigned people or the emergency center. The } \\
\text { collected physiological data are sent periodically to the } \\
\text { web server and stored in the personal health IS (PHR). }\end{array}$ \\
\hline
\end{tabular}




$\begin{array}{llllll}\begin{array}{l}\text { Mamykina et } \\ \text { al. [42] }\end{array} & \text { USA } & \text { C } & \text { MAHI } & \mathbf{X} & \begin{array}{l}\text { Diabetes } \\ \text { patients }\end{array}\end{array}$

MAHI is a mobile application that, through a Bluetoothenabled glucose meter and a Java-enabled cell phone, allows individuals with diabetes to capture rich media records (audio and video) indicating past actions and blood sugar levels, and to share and discuss these records with a diabetes educator through a website.

A monitoring mHealth system based on a smartphone which collects information about a patient's location and

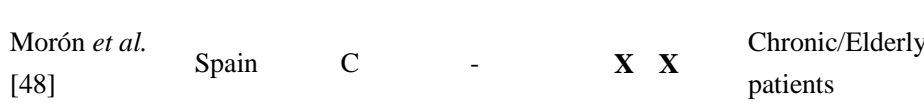
health status (through medical sensors) and detects

patients emergency situations. These data are sent to a central server which allows physicians to get access to patient data and configure the BAN sensors remotely using a conventional web browser.

A mobile phone application for the self-management of people with Type 1 diabetes (T1DM) anytime and anywhere, which collects data from monitoring devices and regularly transfers them to a hospital web server, to be available to the physician. In case of an emergency, the individual can press a button, in order to transmit immediately his/her position to both an emergency contacts Jog Falls is an integrated system for diabetes management consisting of: wearable sensor devices responsible for collecting the physiological and activity data; a smartphone; and a back-end server that is responsible for aggregating and storing the data from all users and for providing the user interface for the physician.

An mHealth system for pervasive sensing of vital signs and

$\begin{array}{lllllll}\begin{array}{l}\text { Nachman } e t \\ \text { al. [52] }\end{array} & \text { USA } & \text { J } & \text { Jog Falls } & \mathbf{X} & \mathbf{X} & \begin{array}{l}\text { Diabetes } \\ \text { patients }\end{array}\end{array}$

\begin{tabular}{|c|c|c|c|c|c|c|}
\hline $\begin{array}{l}\text { Postolache et } \\
\text { al. [49] }\end{array}$ & Portugal & C & - & & $\mathbf{X}$ & $\begin{array}{l}\text { Chronic/Elderly } \\
\text { patients }\end{array}$ \\
\hline $\begin{array}{l}\text { Raso et al. } \\
\text { [50] }\end{array}$ & Spain & C & mPhysio & & $\mathbf{X}$ & $\begin{array}{l}\text { Chronic/Elderly } \\
\text { patients }\end{array}$ \\
\hline $\begin{array}{l}\text { Sagahyroon et } \\
\text { al. } \\
\text { [43] }\end{array}$ & UAE & C & - & $\mathbf{X}$ & $\mathbf{X}$ & $\begin{array}{l}\text { Chronic/Elderly } \\
\text { patients }\end{array}$ \\
\hline
\end{tabular}

motor activities based on a smart wrist-worn device, an Android OS smartphone and web health TeleCare information system.

An iPhone-based rehabilitation system that guides patients in the rehabilitation process and allows the physician to monitor them through a web interface.

A PDA-based health monitoring system that collects and processes data from wearable sensors; sends SMS alerts to the patient's physician if a threshold value is exceeded; and stores the readings until they are uploaded to a hospital database.

UbiMeds is an iPhone application, integrated with the patient's personal health record, that provides automated

Silva et al.

[53]

Canada

C UbiMeds

$\mathbf{X} \mathbf{X}$



\section{Tang et al.}

[46]

Taiwan

C

$-$

$\mathbf{X} \mathbf{X}$

Chronic/Elderly
patients

Chronic/Elderly scheduling, reminders and tracking of prescription drugs' patients intake, including proactive alerts (via SMS) sent to physicians and relatives when the patient fails to adhere to the prescription regime.

A health monitoring system (HIS) which collects patients' physiological signals by portable measurement equipment and then transfers the signals to the healthcare information system through an external SMS device. HIS allows physicians to read the patients' physiological signals and if they are not in the normal range, the system will automatically send a notifying SMS to patients, their families or physicians.

A mobile health monitoring system based on a smartphone with build-in GPS and an RFID ring-type sensor (with an active SOS button). These data are transmitted to a remote server which stores the physiological measurements and tracks the position of the monitored person in real time.

A mobile healthcare application for personalized rehabilitation which, through the combination of a

Zhong et al.

[51]
China

C
$\mathbf{X}$
Chronic/Elderly smartphone and wearable sensors, gives feedback to users, patients and stores and sends data to a remote database for medical monitoring. 


\section{3) Supervised healthcare}

If the information flow between the patient and caregivers includes not only the abnormal data sent in case of emergency, but instead all the patient's physiological signals, stored remotely, are accessible by doctors and families, this involves a further level of complexity in the system structure and can be categorized as supervised healthcare.

Consequently, in addition to the previous building blocks, these mHealth platforms comprise a monitoring system that mainly involves a remote database where the collected physiological data are periodically sent and stored, allowing doctors, family and friends (with different functionality privileges) to view and manage the current and the past conditions of the patient or to configure the BSN sensors remotely, using a conventional web browser. The purposes of these mobile applications are generally related to the monitoring of health parameters [31], [38], [40-49]; the supervision of rehabilitation interventions [12], [50], [51]; detection of falls [39], [52]; or medication adherence [53]. Many of these systems can also combine a component to manage detected emergency situations (assisted healthcare).

However, the main differential offered by these solutions relies on the possibility of caregivers being able to remotely access and supervise both current and past physiological data of the elderly, recorded on the medical database. As a result, it is possible, for instance, through a web interface, to keep caregivers up-to-date with elderly people's evaluation, even using a Web 2.0 social service [41], to share and discuss these records with an educator [42], or to set thresholds for sensors and give advice remotely [47].

\section{4) Continuous monitoring}

This category includes all the functionalities described in the previous categories along with a twoway fully automated and continuous approach (Table 6). In particular, these systems offer a fully automatic analysis of real-time vital signs of the patient, resulting in an automated response in addition to the remote nonautomatic clinical analysis by a specialist (supervised healthcare). This capability is implemented using a reasoning engine, which proactively uses data mining techniques (such as pattern detection) to correlate data from multiple sensors, assess risk levels and help switching to any corresponding real-time assistance responses or preventive actions, appropriate for the individual. Furthermore, it typically also provides effective reporting mechanisms to both patients and caregivers.

For instance, the MediNet system [54] provides personalized recommendations to each patient, over a mobile platform, combining the current and previous readings from monitoring devices with other information about the patient and their medical treatment contents and goals. Depending on the severity of the condition, the system may also notify caregivers or medical officers. Similarly, the MORF platform [55] incorporates mobile monitoring and contextual reasoning, using a fully automated feedback system which removes the need for human monitoring by processing all of the incoming sensor data and taking the required actions accordingly. The peculiarity of these categories of solutions is that, through the automated healthcare intelligence and a truly continuous and ubiquitous two-way information flow, they enable not only reactive actions in response to acute event alerts but also provide preventive personalized recommendations, in support of both patients and health workers

TABle 6 - CONTINUOUS MONITORING SOLUTIONS.

\begin{tabular}{|c|c|c|c|c|c|c|c|c|c|}
\hline Author & Country & Type & Solution & $\mathrm{S}$ & A & $\mathrm{S}$ & C & $\begin{array}{l}\text { Targeted } \\
\text { patients }\end{array}$ & Description \\
\hline $\begin{array}{l}\text { Benlamri and } \\
\text { Docksteader } \\
\text { [55] }\end{array}$ & UK & $\mathrm{J}$ & MORF & & $\mathbf{X}$ & $\mathbf{X}$ & $\mathbf{X}$ & $\begin{array}{l}\text { Chronic } \\
\text { patients }\end{array}$ & $\begin{array}{l}\text { Mobile Ontology-based Reasoning and Feedback (MORF) } \\
\text { health-monitoring system, which monitors a patient's } \\
\text { health status using a mobile phone and takes the required } \\
\text { actions according to the processed incoming sensor data. }\end{array}$ \\
\hline $\begin{array}{l}\text { Boulos et al. } \\
\text { [4] }\end{array}$ & UK & $\mathrm{J}$ & $\begin{array}{l}\text { eCAALYX } \\
\text { Mobile } \\
\text { Platform }\end{array}$ & & $\mathbf{X}$ & $\mathbf{X}$ & $\mathbf{X}$ & $\begin{array}{l}\text { Chronic/Elderly } \\
\text { patients }\end{array}$ & $\begin{array}{l}\text { eCAALYX Mobile Platform (within the eCAALYX EU- } \\
\text { funded project for older people with multiple chronic } \\
\text { conditions) is an Android-based smartphone app which } \\
\text { combines input from sensors located in a wearable smart } \\
\text { garment and in the smartphone, and communicates over the } \\
\text { Internet with a remote server accessible by healthcare } \\
\text { professionals. }\end{array}$ \\
\hline
\end{tabular}




\begin{tabular}{|c|c|c|c|c|c|c|c|c|}
\hline $\begin{array}{l}\text { Bourouis et } \\
\text { al. [58] }\end{array}$ & Algeria & $\mathrm{J}$ & UMHMSE & $\mathbf{X}$ & $\mathbf{X}$ & $\mathbf{X}$ & Elders & $\begin{array}{l}\text { Real-time monitoring system which monitors the elderly } \\
\text { person's mobility, location and vital signs through } \\
\text { wearable sensors (WWBAN), a smartphone as an } \\
\text { Intelligent Central Node (ICN) and an Intelligent Central } \\
\text { Server (ICS) with a web interface, remotely accessible by } \\
\text { family and medical personnel. }\end{array}$ \\
\hline $\begin{array}{l}\text { Jones et al. } \\
\text { [59] }\end{array}$ & Netherlands & $\mathrm{C}$ & $\begin{array}{l}\text { MobiHealth } \\
\text { platform }\end{array}$ & $\mathbf{X}$ & $\mathbf{X}$ & $\mathbf{X}$ & $\begin{array}{l}\text { Epilepsy } \\
\text { patients and } \\
\text { Chronic } \\
\text { patients }\end{array}$ & $\begin{array}{l}\text { Two applications derived from the EU MobiHealth } \\
\text { platform, consisting essentially of wearable sensors, an } \\
\text { MBU (PDA-phone) and a remote server. In the } \\
\text { AWARENESS solution when a seizure is detected, as well } \\
\text { as warning the patient, the application sends a notification } \\
\text { to a remote healthcare location and/or to a voluntary carer. } \\
\text { The health professional can view the locations of patient } \\
\text { and carers via a GIS on the web portal. Alternatively, the } \\
\text { chronic pain application (MYOTEL) allows patients to } \\
\text { view their own biosignals on their handheld device and } \\
\text { provides multi-modal feedback and treatment both locally } \\
\text { on the MBU, and remotely from the professional during } \\
\text { supervised training or assessment. }\end{array}$ \\
\hline $\begin{array}{l}\text { Mohan et al. } \\
\text { [54] }\end{array}$ & $\begin{array}{l}\text { Trinidad e } \\
\text { Tobago }\end{array}$ & $\mathrm{C}$ & MediNet & $\mathbf{X}$ & $\mathbf{X}$ & $\mathbf{X}$ & $\begin{array}{l}\text { Cardiovascular } \\
\text { disease and } \\
\text { Diabetes } \\
\text { patients }\end{array}$ & $\begin{array}{l}\text { MediNet is a mobile phone-based system which provides } \\
\text { personalized recommendations to a patient combining the } \\
\text { information available from the patient with the readings } \\
\text { obtained from the sensors and transmitted to a web server } \\
\text { using a cellular phone network. Depending on the severity } \\
\text { of the condition, the system may also notify caregivers or } \\
\text { medical officers. }\end{array}$ \\
\hline $\begin{array}{l}\text { Paradiso et } \\
\text { al. [60] }\end{array}$ & Italy & $\mathrm{C}$ & HealthWear & $\mathbf{X}$ & $\mathbf{X}$ & $\mathbf{X}$ & $\begin{array}{l}\text { Chronic } \\
\text { patients }\end{array}$ & $\begin{array}{l}\text { HealthWear is a solution for monitoring health conditions } \\
\text { through textile sensors integrated in a garment; a portable } \\
\text { data acquisition and transmission device unit (PPU) that } \\
\text { acquires and transmits the signals; and a remote monitoring } \\
\text { system that stores the data transmitted, and which } \\
\text { continuously monitors vital health parameters, generates } \\
\text { alerts in case of critical situations, and gives access to the } \\
\text { central database to doctors and other health professionals. }\end{array}$ \\
\hline $\begin{array}{l}\text { Suh et al. } \\
\text { [61] }\end{array}$ & USA & $\mathrm{C}$ & WANDA B. & $\mathbf{X}$ & $\mathbf{X}$ & $\mathbf{X}$ & $\begin{array}{l}\text { Heart failure } \\
\text { patients }\end{array}$ & $\begin{array}{l}\text { WANDA B. (weight and activity blood pressure } \\
\text { monitoring system) is an integrated architecture of } \\
\text { different systems that collects weight, blood pressure, } \\
\text { activity, and patients' information through daily SMS } \\
\text { surveys. These data are transmitted daily to a web server } \\
\text { and are accessible through both an iPhone application and } \\
\text { a web application, allowing caregivers to monitor patients } \\
\text { in real time. If the values transmitted are out of the } \\
\text { threshold range, it alerts healthcare providers (via SMS, } \\
\text { email and phone) to take action. }\end{array}$ \\
\hline $\begin{array}{l}\text { Villalba et } \\
\text { al. [62] }\end{array}$ & Italy & $\mathrm{J}$ & $\begin{array}{c}\text { part of } \\
\text { MyHeart } \\
\text { Project }\end{array}$ & $\mathbf{X}$ & $\mathbf{X}$ & $\mathbf{X}$ & $\begin{array}{l}\text { Heart failure } \\
\text { patients }\end{array}$ & $\begin{array}{l}\text { A heart failure management system composed of: a PDA } \\
\text { that receives data from ad hoc wearable measuring sensors } \\
\text { and other commercial devices, a remote platform that } \\
\text { includes the processing server (that analyzes all data), } \\
\text { databases, and a web portal that provides ubiquitous access } \\
\text { to professionals. }\end{array}$ \\
\hline $\begin{array}{l}\text { Wan et al. } \\
{[63]}\end{array}$ & Ireland & $\mathrm{J}$ & OutCare & $\mathbf{X}$ & $\mathbf{X}$ & $\mathbf{X}$ & $\begin{array}{l}\text { Dementia } \\
\text { patients }\end{array}$ & $\begin{array}{l}\text { OutCare is an outdoor monitoring system, tailored for } \\
\text { citizens with dementia, consisting of the patient's mobile } \\
\text { phone with GPS sensor, the carer's mobile phone (that } \\
\text { receives emergency alerts and allows patient profile } \\
\text { inquiry and tracking) and a web server (responsible for } \\
\text { patient profiling, data recording, analyzing and } \\
\text { visualization through a convenient interface). }\end{array}$ \\
\hline
\end{tabular}




\section{B. Demographics}

This section reports aggregate demographic data extracted from the 42 relevant papers, 29 of which were conference proceedings and 13 were journal papers. Although the chosen data range was too short to allow for consideration of possible trends, Figure 4 shows that most of the included papers were published in 2010, while at the beginning of 2012, no publication was found that matched our criteria. The graph below illustrates the frequency of the studies authored in different continents. Most of the mHealth projects were from the European Union (55\%), followed by Asia (26\%) and North America (14\%) while the author of only one publication was affiliated to an African university.
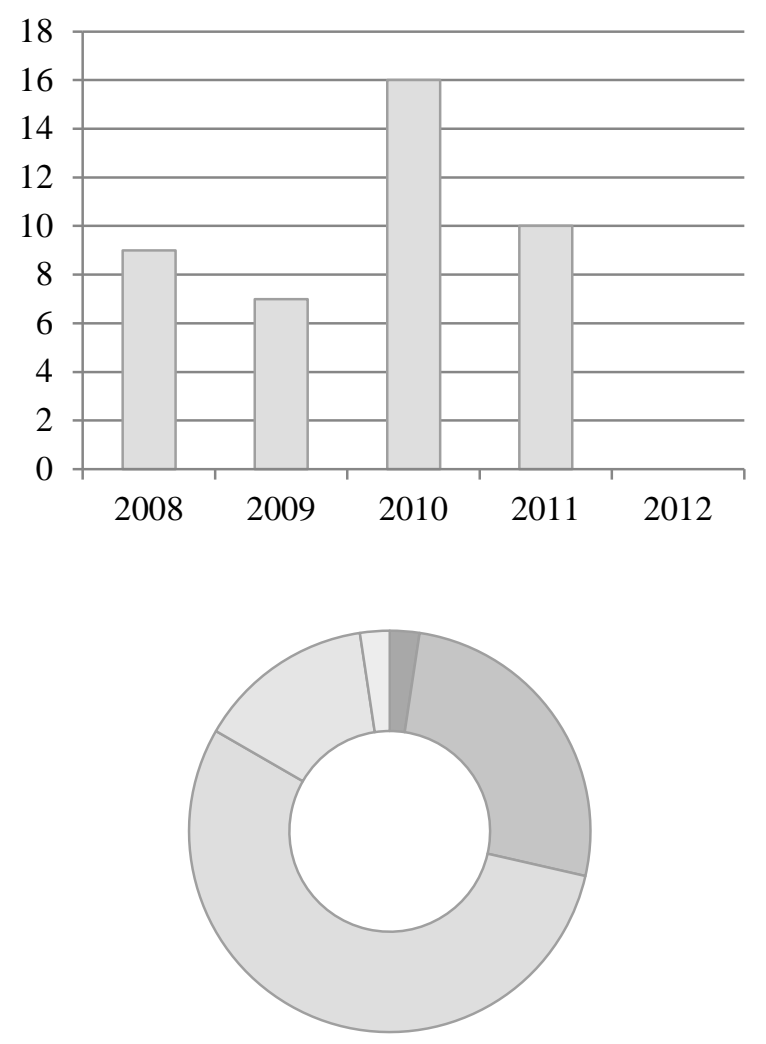

$\square$ AFRICA $\square$ ASIA $\square$ EU $\square$ NA $\square$ SA

FIGURE 4 - FREQUENCY OF THE PAPERS PER YEAR AND PER CONTINENT.

\section{DISCUSSION}

In contrast to healthcare access, mobile access is becoming almost ubiquitous worldwide. Undoubtedly, the rising cost of care driven by chronic diseases and aging populations and the increasing penetration of smartphones as well as the 3G and 4G networks across the world provide a significant boost to the use of mobile communication and devices in providing ubiquitous healthcare services in both developed and developing countries [6]. Although mHealth solutions and technologies for the elderly are steadily proliferating, they differ greatly in scope and scale, and no standardized definition of mHealth has been established to date [56]. Furthermore, the variety of technologies, the increasing number of applications and newly introduced terminology have made it impossible to manipulate these solutions as a single homogenous ensemble, taking for granted the underlying system structure.

There are several literature surveys and taxonomies which seek to bring order to the mHealth domain. However, to the best of our knowledge, no systematic review has been conducted in order to portray a comprehensive overview of the different types of mobile health platforms currently being implemented, especially for the elderly or patients with chronic conditions. In particular, most of the existing reviews categorize mHealth solutions for the elderly based on the type of services on which they focus [10], [11], [57]. For example, Ludwig et al. [10], carried out a systematic overview of the health-enabling technologies for the elderly reported in the literature and identified six possible archetypical service categories, namely: handling adverse conditions, assessing state of health, consultation and education, motivation and feedback, service ordering, and social inclusion.

Even though some publications emphasised the technological configurations of the available platforms, they only considered a narrow type of possible mHealth solutions, such as the smartphone apps [9], [64] or interventions that were strictly phone-based [65] instead of, more comprehensively, "every mobile platform ... which [provides] access to medical advice and information" (see section III.C). Furthermore, there was a paucity of research on elderly or chronic patients. Thus this research reports the unique applications of mHealth in transforming healthcare for people with chronic diseases and elders; however, some challenges remain.

The study articulates these challenges in Table 7 based on the synthesis of the systematic reviews. These challenges include further improvements in data capture/acquisition, data processing in the local environment close to the patient, wireless data transport, quality of service provision, storage cloud, user interface, and overall platform. In addressing these challenges, the study reports the relevant technological developments that might shape the landscape of mHealth applications for people with chronic diseases and elders in the near future 


\begin{tabular}{|c|c|c|}
\hline $\begin{array}{l}\text { Data } \\
\text { capture/acquisition }\end{array}$ & $\begin{array}{l}\text { Developing pervasive sensors for the body - in the current state of the art, } \\
\text { the sensors are quite obtrusive and inconvenient. Can we embed the } \\
\text { sensors in our garments? Can we embed the sensors in our body? }\end{array}$ & Developments in nanotechnology \\
\hline $\begin{array}{l}\text { Data processing in } \\
\text { local environment }\end{array}$ & $\begin{array}{l}\text { Developing systems that maximize local analysis close to the patient. } \\
\text { Such systems will guarantee timely data processing in the absence of } \\
\text { cellular bandwidth. }\end{array}$ & $\begin{array}{l}\text { Developments in processing platforms } \\
\text { such as the smartphones (iPhone, } \\
\text { Android, etc.) }\end{array}$ \\
\hline $\begin{array}{l}\text { Wireless data } \\
\text { transport }\end{array}$ & $\begin{array}{l}\text { Managing bandwidth for massive application of mHealth care. There are } \\
\text { five billion phones in the world that can be potential entry points into the } \\
\text { mHealth market. Therefore, bandwidth management techniques and } \\
\text { quality of service (QoS) will need special attention. }\end{array}$ & $\begin{array}{l}\text { Deployment of } 4 \mathrm{G} \text { networks } \\
\text { Deployment of cloud services } \\
\text { Expected high demand of services }\end{array}$ \\
\hline $\begin{array}{l}\text { Quality of service } \\
\text { provision in } \\
\text { cellular networks }\end{array}$ & $\begin{array}{l}\text { Classification of mHealth data is required and associated QoS provision } \\
\text { should be improved in the field of priority data (e.g., emergency fall } \\
\text { detection), real-time interactive data (e.g., video consultation), near real- } \\
\text { time data (e.g., continuous monitoring) or, health record-related data. }\end{array}$ & $\begin{array}{l}\text { Deployment of } 4 \mathrm{G} \text { networks } \\
\text { Prevalence of smartphones that have } \\
\text { processing and storage capabilities }\end{array}$ \\
\hline Storage cloud & $\begin{array}{l}\text { Integration of data transport with cloud storage - it can enable } \\
\text { accountability of the carriers for data. }\end{array}$ & Development of cloud services \\
\hline Security & $\begin{array}{l}\text { Addressing the privacy and security concerns in mHealth. Security needs } \\
\text { to be integrated into the entire mHealth loop, such as, the smartphone, the } \\
\text { sensors, the local communication between the sensors and the smartphone, } \\
\text { data transmission between the local system and the remote server, and the } \\
\text { server that processes and stores the health data. }\end{array}$ & Prevalence of security attacks \\
\hline User interface & $\begin{array}{l}\text { Designing a flexible user interface to make mHealth accessible for } \\
\text { patients, especially considering elderly patients who may have vision } \\
\text { problems and/or may be technologically-challenged. }\end{array}$ & $\begin{array}{l}\text { Smartphones with processing and } \\
\text { storage capabilities as well as having a } \\
\text { convenient user interface. }\end{array}$ \\
\hline Platforms & $\begin{array}{l}\text { Designing mHealth applications for feature phones (not only for } \\
\text { smartphones) such as SMS-based applications. }\end{array}$ & $\begin{array}{l}\text { High cost of smartphones and } \\
\text { associated data plans }\end{array}$ \\
\hline
\end{tabular}

TABle 7 - Future Challenges.

\section{CONCLUSION}

Our main objective in this review was to propose a comprehensive overview and classification of a broad range of mobile health solutions that have been implemented for elderly people and patients with chronic conditions. To pursue this objective, the study has analyzed not only mobile-based units (MBUs) with processing and communication capabilities (e.g. smartphone, tablet, PDA, PERS, specific-purpose device, etc.) but also the overall mobile platform architecture. It is evident that a higher and more inclusive "big picture" of each existing solution using mobile devices and communication can provide assistance to the elderly and patients with chronic conditions. It can also help to reach an exhaustive evidence-based taxonomy that differentiates the incomparable levels of complexity in terms of people, technological components and information involved in the current mHealth platforms. This study has successfully established the categories of homogenous solutions that will further enhance the scope of this research. The findings of the study will facilitate the assessment of the drivers of market adoption, user acceptance, cost and maturity of each category of solution. In other words, these findings will also help to set directions for scalable and sustainable mobile health interventions for the elderly.

The review presented in this paper has three main limitations that it is important to acknowledge. Firstly, it is based on a systematic search of mHealth solutions available in the existing literature from various scientific and technological online databases. It does not include commercial mHealth solutions that have been developed in recent years for the elderly, but not reported or cited in any publication. This is because 
there is currently no systematic way to obtain a comprehensive overview of commercial products [65]. Secondly, the systematic review procedure itself has the limitation that it was heavily dependent on the chosen keywords [18]. Since no standardized definition of mHealth has been established [56], we derived our search terms (section III.A) and inclusion/exclusion criteria (section III.C) by selecting a recent comprehensive definition of mHealth and by considering the mobility requirement at least from the patient-centric perspective. Finally, this study exclusively focuses on mobile health solutions targeted to meet the specific needs of the elderly or patients with chronic conditions.

Overall, the findings of the study make it evident that mobile technology transforms healthcare in aging societies by providing solutions in terms of: selfhealthcare, assisted healthcare, supervised healthcare, and continuous monitoring.

These findings will help to realize the potential of mobile technology in developing information systems for each category and in measuring health objectives and desired outcomes.

\section{ACKNOWLEDGEMENT}

This research has been carried out as part of the global initiative on the assessment of mHealth involving 12 countries (Prof Cristina Massella leads the Italian contribution through the Politecnico di Milano) under the overall leadership of Prof. Pradeep Ray of the Asia Pacific ubiquitous Healthcare research Centre (APuHC) at the University of New South Wales, Australia.

\section{REFERENCES}

[1] United Nations Department of Economic and Social Affairs (DESA) - Population Division, "World Population Ageing 2009," 2009.

[2] WHO, "Global status report on noncommunicable diseases 2010,” Geneva, 2011.

[3] International Telecommunication Union, "Measuring the Information Society 2010,” 2010.

[4] M. Boulos, S. Wheeler, C. Tavares, and R. Jones, "How smartphones are changing the face of mobile and participatory healthcare: an overview, with example from eCAALYX," BioMedical Engineering OnLine, vol. 10, no. 1, p. 24, 2011.

[5] Juniper Research, "Mobile Healthcare Opportunities, Monitoring Applications \& mHealth Strategies 2010-2014,” Apr. 2010.

[6] PwC, "Touching lives through mobile health - Assessment of the global market opportunity," 2012.

[7] "MobileHealthLive," GSMA deployments tracker, Mar-2012. [Online]. http://apps.wirelessintelligence.com/health/tracker/.

[8] A. O’Brien and R. Mac Ruairí, "Survey of Assistive Technology Devices and Applications for Aging in Place," 2009, pp. 7-12.

[9] J. Gao and A. Koronios, "Mobile Application Development for Senior Citizens,” 2010, pp. 214-223.
[10] W. Ludwig, K. H. Wolf, C. Duwenkamp, N. Gusew, N. Hellrung, M. Marschollek, M. Wagner, and R. Haux, "Healthenabling technologies for the elderly-An overview of services based on a literature review," Computer Methods and Programs in Biomedicine, 2011.

[11] AARP International, "Mobile Health for Independent Living Landscape Report," 2011.

[12] L. K. Au, M. Batalin, B. Jordan, C. Xu, A. A. T. Bui, B. Dobkin, and W. J. Kaiser, "Demonstration of WHI-FIT: a wireless-enabled cycle restorator," 2010, pp. 190-191.

[13] R. S. H. Istepanian, S. Hu, N. Y. Philip, and A. Sungoor, "The potential of Internet of m-health Things 'm-IoT' for noninvasive glucose level sensing,” in 2011 Annual International Conference of the IEEE Engineering in Medicine and Biology Society,EMBC, 2011, pp. 5264-5266.

[14] W. J. Orlikowski and C. S. Iacono, "Research commentary: desperately seeking the ' IT' in IT research - A call to theorizing the IT artifact," Information systems research, vol. 12, no. 2, pp. 121-134, 2001.

[15] R. Bashshur, G. Shannon, E. Krupinski, and J. Grigsby, "The Taxonomy of Telemedicine," Telemedicine and e-Health, vol. 17, no. 6, pp. 484-494, Jul. 2011.

[16] D. Tranfield, D. Denyer, and P. Smart, "Towards a methodology for developing evidence-informed management knowledge by means of systematic review," British journal of management, vol. 14, no. 3, pp. 207-222, 2003.

[17] B. Kitchenham, "Procedures for performing systematic reviews," Keele, UK, Keele University, vol. 33, 2004.

[18] B. Kitchenham, O. Pearl Brereton, D. Budgen, M. Turner, J. Bailey, and S. Linkman, "Systematic literature reviews in software engineering - A systematic literature review," Information and Software Technology, vol. 51, no. 1, pp. 7-15, 2009.

[19] O. Dieste, A. Grimán, and N. Juristo, "Developing search strategies for detecting relevant experiments," Empirical Software Engineering, vol. 14, no. 5, pp. 513-539, Nov. 2008.

[20] S. Akter and P. Ray, "mHealth - an Ultimate Platform to Serve the Unserved," Yearb Med Inform, pp. 94-100, 2010.

[21] M. Shopov, G. Spasov, and G. Petrova, "Architectural models for realization of web-based personal health systems," in Proceedings of the International Conference on Computer Systems and Technologies and Workshop for PhD Students in Computing, New York, NY, USA, 2009, pp. 53:1-53:6.

[22] W. Ludwig, K. H. Wolf, C. Duwenkamp, N. Gusew, N. Hellrung, M. Marschollek, T. Von Bargen, M. Wagner, and R. Haux, "Health information systems for home telehealth services - a nomenclature for sensor-enhanced transinstitutional information system architectures," Informatics for Health and Social Care, vol. 35, no. 3-4, pp. 211-225, 2010.

[23] R. de Oliveira, M. Cherubini, and N. Oliver, "MoviPill: improving medication compliance for elders using a mobile persuasive social game," in Proceedings of the 12th ACM international conference on ubiquitous computing, New York, NY, USA, 2010, pp. 251-260.

[24] D. de Jager, A. L. Wood, G. V. Merrett, B. M. Al-Hashimi, K. O'Hara, N. R. Shadbolt, and W. Hall, "A low-power, distributed, pervasive healthcare system for supporting memory," in Proceedings of the First ACM MobiHoc Workshop on Pervasive Wireless Healthcare, New York, NY, USA, 2011, pp. 5:1-5:7.

[25] R. Hervás, A. Garcia-Lillo, and J. Bravo, "Mobile Augmented Reality Based on the Semantic Web Applied to Ambient Assisted Living," Ambient Assisted Living, pp. 17-24, 2011.

[26] R. R. Fletcher, S. Tam, O. Omojola, R. Redemske, S. Fedor, and J. M. Moshoka, "Mobile application and wearable sensors for use in cognitive behavioral therapy for drug addiction and PTSD," in 2011 5th International Conference on Pervasive Computing Technologies for Healthcare (PervasiveHealth), 2011, pp. 202-203.

[27] G. Pioggia, G. Tartarisco, G. Ricci, L. Volpi, G. Siciliano, D. De Rossi, and S. Bonfiglio, "A wearable pervasive platform for the intelligent monitoring of muscular fatigue," in Intelligent 
Systems Design and Applications (ISDA), 2010 10th International Conference on, 2010, pp. 132-135.

[28] A. K. Bourke, P. W. J. van de Ven, A. Chaya, G. ÓLaighin, and J. Nelson, "Design and test of a long-term fall detection system incorporated into a custom vest for the elderly," in Signals and Systems Conference, 208. (ISSC 2008). IET Irish, 2008, pp. 307-312.

[29] S. Y. Chang, C. F. Lai, H. C. J. Chao, J. H. Park, and Y. M. Huang, "An Environmental-Adaptive Fall Detection System on Mobile Device,” Journal of Medical Systems, pp. 1-14, 2011.

[30] J. Dai, Xiaole Bai, Zhimin Yang, Zhaohui Shen, and Dong Xuan, "PerFallD: A pervasive fall detection system using mobile phones," in 2010 8th IEEE International Conference on Pervasive Computing and Communications Workshops (PERCOM Workshops), 2010, pp. 292-297.

[31] J. H. Hong, E. J. Cha, and T. S. Lee, "A belt-type biomedical mobile device," Journal of Korean Society of Medical Informatics, vol. 15, no. 3, pp. 351-358, 2009.

[32] L. U Hernandez Munoz, S. I. Woolley, and C. Baber, "A mobile health device to help people with severe allergies," in Second International Conference on Pervasive Computing Technologies for Healthcare, 2008. PervasiveHealth 2008, 2008, pp. 8-10.

[33] H. Kailanto, E. Hyvarinen, and J. Hyttinen, "Mobile ECG measurement and analysis system using mobile phone as the base station," in Second International Conference on Pervasive Computing Technologies for Healthcare, 2008. PervasiveHealth 2008, 2008, pp. 12-14.

[34] I. C. Lopes, B. Vaidya, and J. J. P. C. Rodrigues, "Towards an autonomous fall detection and alerting system on a mobile and pervasive environment,” Telecommunication Systems, pp. 1-12, 2011.

[35] Sing-Hui Toh, Seung-Chul Lee, and Wan-Young Chung, "WSN Based Personal Mobile Physiological Monitoring and Management System for Chronic Disease," in Third International Conference on Convergence and Hybrid Information Technology, 2008. ICCIT '08, 2008, vol. 1, pp. 467-472.

[36] S. Wagner, "OpenCare project personal communication device," in 3rd International Conference on Pervasive Computing Technologies for Healthcare, 2009. PervasiveHealth 2009, 2009, pp. 1-3.

[37] G. Yavuz, M. E. Kocak, G. Ergun, H. Alemdar, H. Yalcin, O. D. Incel, L. Akarun, and C. Ersoy, "A Smartphone Based Fall Detector with Online Location Support," Proc. of PhoneSense'10, 2010.

[38] V. Galetic, I. Benc, S. Desic, J. Krizanic, M. Mosmondor, A. Grguric, D. Gvozdanovic, D. Huljenic, L. Damjanic, and M. Ravic, "Ericsson mobile health solution overview," in 2010 Proceedings of the 33rd International Convention MIPRO, 2010, pp. 350-354.

[39] Y. M. Hsiao, W. T. Liu, W. S. Chen, Y. Lu, J. P. Yang, and Y. S. Chu, "Design and implementation of a healthcare system with fall detection," presented at the International Symposium on Bioelectronics and Bioinformatics (ISBB), 2011, pp. 131134.

[40] H. J. Lee, S. H. Lee, K.-S. Ha, H. C. Jang, W.-Y. Chung, J. Y. Kim, Y.-S. Chang, and D. H. Yoo, "Ubiquitous healthcare service using Zigbee and mobile phone for elderly patients," International Journal of Medical Informatics, vol. 78, no. 3, pp. 193-198, Mar. 2009.

[41] D. López-de-Ipiña, I. Díaz-de-Sarralde, and J. Garc’ia-Zubia, "An ambient assisted living platform integrating RFID data-ontag care annotations and twitter," J Univers Comput Sci, vol. 16, no. 12, pp. 1521-1538, 2010.

[42] L. Mamykina, E. Mynatt, P. Davidson, and D. Greenblatt, "MAHI: investigation of social scaffolding for reflective thinking in diabetes management," in Proceedings of the twenty-sixth annual SIGCHI conference on Human factors in computing systems, New York, NY, USA, 2008, pp. 477-486.

[43] A. Sagahyroon, H. Rady, A. Ghazy, and U. Suleman, "A wireless healthcare monitoring platform," in International
Conference on Innovations in Information Technology, 2008. IIT 2008., 2008, pp. 126-129.

[44] Yu-Chi Wu, Pei-Fan Chen, Zhi-Huang Hu, Chao-Hsu Chang, Gwo-Chuan Lee, and Wen-Ching Yu, "A Mobile Health Monitoring System Using RFID Ring-Type Pulse Sensor,” in Eighth IEEE International Conference on Dependable, Autonomic and Secure Computing, 2009. DASC '09, 2009, pp. 317-322.

[45] S. G. Mougiakakou, I. Kouris, D. Iliopoulou, A. Vazeou, and D. Koutsouris, "Mobile technology to empower people with Diabetes Mellitus: Design and development of a mobile application,” 2009, pp. 1-4.

[46] W. T. Tang, C. M. Hu, and C. Y. Hsu, "A mobile phone based homecare management system on the cloud," 2010, vol. 6, pp. 2442-2445.

[47] Z. Lv, F. Xia, G. Wu, L. Yao, and Z. Chen, "iCare: A Mobile Health Monitoring System for the Elderly," in arXiv:1011.3852, 2010.

[48] M. Morón, A. G’omez-Jaime, J. Luque, and E. Casilari, "Development and evaluation of a python telecare system based on a bluetooth body area network," EURASIP Journal on Wireless Communications and Networking, vol. 2011, p. 2, 2011.

[49] O. Postolache, P. S. Girão, M. Ribeiro, M. Guerra, J. Pincho, F. Santiago, and A. Pena, "Enabling telecare assessment with pervasive sensing and Android OS smartphone,” 2011, pp. 288-293.

[50] I. Raso, R. Hervás, and J. Bravo, "m-Physio: Personalized accelerometer-based physical rehabilitation platform,” 2010, pp. 416-421.

[51] Sheng Zhong, Li Wang, A. M. Bernardos, and Mei Song, “An accurate and adaptive pedometer integrated in mobile health application,” in IET International Conference on Wireless Sensor Network, 2010. IET-WSN, 2010, pp. 78-83.

[52] L. Nachman, A. Baxi, S. Bhattacharya, V. Darera, P. Deshpande, N. Kodalapura, V. Mageshkumar, S. Rath, J. Shahabdeen, and R. Acharya, "Jog falls: A pervasive healthcare platform for diabetes management," Pervasive Computing, pp. 94-111, 2010.

[53] J. M. Silva, A. Mouttham, and A. El Saddik, "UbiMeds: a mobile application to improve accessibility and support medication adherence," in Proceedings of the 1st ACM SIGMM international workshop on media studies and implementations that help improving access to disabled users, New York, NY, USA, 2009, pp. 71-78.

[54] P. Mohan, D. Marin, S. Sultan, and A. Deen, "MediNet: Personalizing the self-care process for patients with diabetes and cardiovascular disease using mobile telephony," in 30th Annual International Conference of the IEEE Engineering in Medicine and Biology Society, 2008. EMBS 2008, 2008, pp. 755-758.

[55] R. Benlamri and L. Docksteader, "MORF: A Mobile HealthMonitoring Platform,” IT Professional, vol. 12, no. 3, pp. 1825, Jun. 2010.

[56] WHO, "Mhealth - New horizons for health through mobile technologies," Global Observatory for eHealth series - Volume 3, 2011.

[57] Center for Technology and Ageing, "mHealth Technologies: Applications to Benefit Older Adults," 2011.

[58] A. Bourouis, M. Feham, and A. Bouchachia, "Ubiquitous Mobile Health Monitoring System for Elderly (UMHMSE)," Arxiv preprint arXiv:1107.3695, 2011.

[59] V. M. Jones, R. Huis in't Veld, T. Tonis, R. B. Bults, B. van Beijnum, I. Widya, M. Vollenbroek-Hutten, and H. Hermens, "Biosignal and context monitoring: Distributed multimedia applications of Body Area Networks in healthcare," in 2008 IEEE 10th Workshop on Multimedia Signal Processing, 2008, pp. 820-825.

[60] R. Paradiso, A. Alonso, D. Cianflone, A. Milsis, T. Vavouras, and C. Malliopoulos, "Remote health monitoring with wearable non-invasive mobile system: The Healthwear project," 2008, pp. 1699-1702. 
[61] M. Suh, L. S. Evangelista, V. Chen, W.-S. Hong, J. Macbeth, A. Nahapetian, F.-J. Figueras, and M. Sarrafzadeh, "WANDA B.: Weight and activity with blood pressure monitoring system for heart failure patients," in World of Wireless Mobile and Multimedia Networks (WoWMoM), 2010 IEEE International Symposium on a, 2010, pp. 1-6.

[62] E. Villalba, D. Salvi, M. Ottaviano, I. Peinado, M. Arredondo, and A. Akay, "Wearable and mobile system to manage remotely heart failure," Information Technology in Biomedicine, IEEE Transactions on, vol. 13, no. 6, pp. 990996, 2009.

[63] J. Wan, C. Byrne, G. O’Hare, and M. O’Grady, "OutCare: supporting dementia patients in outdoor scenarios,” KnowledgeBased and Intelligent Information and Engineering Systems, pp. 365-374, 2010.

[64] C. Liu, Q. Zhu, K. A. Holroyd, and E. K. Seng, "Status and trends of mobile-health applications for iOS devices: A developer's perspective," Journal of Systems and Software, vol. 84, no. 11, pp. 2022-2033, Nov. 2011.

[65] P. Klasnja and W. Pratt, "Healthcare in the pocket: Mapping the space of mobile-phone health interventions," Journal of Biomedical Informatics, no. 0, Jan. 2012. 